\title{
Characterization of Serratia marcescens, S. liquefaciens, S. plymuthica and $S$. marinorubra by the Electrophoretic Patterns of their Esterases
}

\author{
By Рн. GOULLET \\ Laboratoire de Microbiologie, Faculté de Médecine Xavier-Bichat, \\ Université Paris VII, Institut Biomédical des Cordeliers, \\ 21, rue de l'École de Médecine, 75020 Paris Cedex 06, France
}

(Received 24 April 1978)

\begin{abstract}
Esterases of 62 Serratia marcescens, $S$. liquefaciens, $S$. plymuthica and S. marinorubra strains were analysed by horizontal slab electrophoresis in polyacrylamide-agarose gel. Five principal bands hydrolysed $\beta$-naphthyl acetate but differed in their range of activity towards other substrates and in their sensitivity to di-isofluoropropyl phosphate. Additional bands were detected in some strains of $S$. marcescens and $S$. marinorubra. The comparative distribution of bands showed that the four Serratia species were characterized by distinct electrophoretic patterns of their esterases. Serratia marcescens, S. liquefaciens and S. plymuthica appeared to be more closely related to one another than to $S$. marinorubra. In the case of $S$.plymuthica and $S$. marinorubra, congruence was found between biovars and esterase patterns. The numerous electrophoretypes observed within Serratia species might provide useful epidemiological markers.
\end{abstract}

\section{INTRODUCTION}

Previous investigations have revealed that esterases of several taxa in the family Enterobacteriaceae (Goullet, 1973, 1975, 1977; Goullet \& Richard, 1977) give distinct and reproducible species-specific zymogram banding patterns when assayed after electrophoresis in polyacrylamide-agarose gel. In the present study, the esterases produced by the four Serratia species recognized by Grimont et al. $(1977 a, b)$ were examined.

\section{METHODS}

The names and sources of the test strains are given in Table 1. Growth conditions, preparation of extracts, inhibition by di-isofluoropropyl phosphate (DFP), protein estimation, acrylamide-agarose gel electrophoresis, esterase staining and estimation of electrophoretic mobility $\left(\boldsymbol{M}_{\boldsymbol{F}}\right.$ value) have all been described previously (Goullet, 1977).

\section{RESULTS}

The esterase profiles resolved from multiple runs of the same and different soluble extracts from each strain were reproducible. Electrophoretic relationships were established between the strains by numerous replicate assays comparing esterase bands in adjacent positions on the same gel. Esterase bands were found in all of the test strains.

Five principle esterase bands varying in sharpness and colour intensity, designated as $E_{1}, E_{2}, E_{3}, E_{4}$ and $E_{5}$ in order of decreasing electrophoretic mobility, were defined (Fig. $1 \mathrm{a}$ ). The $E_{1}$ band hydrolysed $\alpha$-naphthyl acetate and to a lesser degree $\alpha$-naphthyl butyrate, indoxyl acetate and $\beta$-naphthyl acetate; the $\mathrm{E}_{2}$ band hydrolysed $\alpha$ - and $\beta$-naphthyl acetates; 
Table 1. Serratia species examined

\begin{tabular}{|c|c|c|c|c|c|c|}
\hline Code & Organism & Strain* & Biovar $\dagger$ & Source $\ddagger$ & $30^{\circ} \mathrm{C}$ & $37^{\circ} \mathrm{C}$ \\
\hline $\begin{array}{r}1 \\
2 \\
3 \\
4 \\
4 \\
5 \\
6 \\
7 \\
8 \\
9 \\
10 \\
11 \\
12 \\
13 \\
14 \\
15 \\
16\end{array}$ & $\begin{array}{l}\text { S. marcescens } \\
\text { S. marcescens } \\
\text { S. marcescens } \\
\text { S. marcescens } \\
\text { S. marcescens } \\
\text { S. marcescens } \\
\text { S. marcescens } \\
\text { S. marcescens } \\
\text { S. marcescens } \\
\text { S. marcescens } \\
\text { S. marcescens } \\
\text { S. marcescens } \\
\text { S. marcescens } \\
\text { S. marcescens } \\
\text { S. marcescens } \\
\text { S. marcescens }\end{array}$ & $\begin{array}{l}\text { LM } 24.70 \\
\text { LM } 37.70 \\
\text { LM } 7.71 \\
\text { LM } 2.73 \\
\text { LM } 5.73 \\
\text { LM } 25.73 \\
\text { LM } 26.73 \\
\text { LM } 8.74 \\
\text { LM } 1.75 \\
\text { LM } 7.75 \\
\text { LM } 12.75 \\
\text { LM } 16.75 \\
\text { LM } 20.75 \\
\text { LM } 29.75 \\
\text { LM } 38.75 \\
\text { LM } 41.75\end{array}$ & & $\begin{array}{l}\text { Blood, Firminy, } 1970 \\
\text { Blood, Pontivy } \\
\text { Nasal sample, Tangier } \\
\text { Insect, Greece } \\
\text { Pus, Toulon } \\
\text { Pus, Perpignan } \\
\text { Blood, Coulommiers } \\
\text { Urine, Paris } \\
\text { Urine, Paris } \\
\text { Urine, Paris } \\
\text { Bat, Madagascar } \\
\text { Urine, Levallois-Perret } \\
\text { Urine, Colmar } \\
\text { Urine, Belfort } \\
\text { Blood, Tangier } \\
\text { Faeces, Limoges }\end{array}$ & E & $\begin{array}{l}\text { E, S } \\
\text { E } \\
\text { E, S } \\
\text { E, S } \\
\text { E, S } \\
\text { E, S } \\
\text { E, S } \\
\text { E, S } \\
\text { E, S } \\
\text { E, S } \\
\text { E, S } \\
\text { E, S } \\
\text { E, S } \\
\text { E, S } \\
\text { E, S } \\
\text { E, S }\end{array}$ \\
\hline $\begin{array}{l}17 \\
18 \\
19 \\
20 \\
21 \\
22 \\
23 \\
24 \\
25 \\
26 \\
27 \\
28 \\
29 \\
30 \\
31 \\
32\end{array}$ & $\begin{array}{l}\text { S. liquefaciens } \\
\text { S. liquefaciens } \\
\text { S. liquefaciens } \\
\text { S. liquefaciens } \\
\text { S. liquefaciens } \\
\text { S. liquefaciens } \\
\text { S. liquefaciens } \\
\text { S. liquefaciens } \\
\text { S. liquefaciens } \\
\text { S. liquefaciens } \\
\text { S. liquefaciens } \\
\text { S. liquefaciens } \\
\text { S. liquefaciens } \\
\text { S. liquefaciens } \\
\text { S. liquefaciens } \\
\text { S. liquefaciens }\end{array}$ & $\begin{array}{l}\text { LM } 1.68 \\
\text { LM } 2.68 \\
\text { LM } 3.68 \\
\text { LM } 8.68 \\
\text { LM } 9.68 \\
\text { LM } 12.68 \\
\text { LM } 13.70 \\
\text { LM } 2.71 \\
\text { LM } 4.71 \\
\text { LM } 6.71 \\
\text { LM } 5.72 \\
\text { LM } 1.73 \\
\text { LM } 21.74 \\
\text { LM } 1.75 \\
\text { LM } 2.75 \\
\text { LM } 23.75\end{array}$ & $\begin{array}{l}\text { C1b } \\
\text { Cla } \\
\text { C1b } \\
\text { C1a } \\
\text { C1a } \\
\text { C1a }\end{array}$ & $\begin{array}{l}\text { Water, Tangier } \\
\text { Water, Tangier } \\
\text { Urine, Tangier } \\
\text { CDC 2224-64 } \\
\text { CDC 5155-57 } \\
\text { CDC 4733-51 } \\
\text { Veal, France, 1970 } \\
\text { Blood, Fresnes, } 1971 \\
\text { Urine, Tangier, 1971 } \\
\text { Water, Le Pecq } \\
\text { Veal, Alfort } \\
\text { Butterfly, France } \\
\text { Throat, Villejuif } \\
\text { Urine, Tangier } \\
\text { Catheter, Paris } \\
\text { Blood, Garches }\end{array}$ & $\begin{array}{l}\mathbf{E} \\
\mathbf{E}\end{array}$ & $\begin{array}{l}E \\
E \\
E, S \\
E \\
E \\
E \\
E \\
E \\
E \\
E \\
E \\
E \\
E, S \\
E \\
E \\
E, S\end{array}$ \\
\hline $\begin{array}{l}33 \\
34 \\
35 \\
36 \\
37 \\
38 \\
39 \\
40 \\
41 \\
42 \\
43 \\
44 \\
45 \\
46 \\
47\end{array}$ & $\begin{array}{l}\text { S. plymuthica } \\
\text { S. plymuthica } \\
\text { S. plymuthica } \\
\text { S. plymuthica } \\
\text { S. plymuthica } \\
\text { S. plymuthica } \\
\text { S. plymuthica } \\
\text { S. plymuthica } \\
\text { S. plymuthica } \\
\text { S. plymuthica } \\
\text { S. plymuthica } \\
\text { S. plymuthica } \\
\text { S. plymuthica } \\
\text { S. plymuthica } \\
\text { S. plymuthica }\end{array}$ & $\begin{array}{l}\text { G } 33 \\
\text { G } 34 \\
\text { G } 289 \\
\text { G } 299 \\
\text { G } 325 \\
\text { G } 329 \\
\text { G } 392 \\
\text { G } 500 \\
\text { G } 501 \\
\text { G } 502 \\
\text { G } 510 \\
\text { G } 512 \\
\text { G } 515 \\
\text { G } 516 \\
\text { G } 517\end{array}$ & $\begin{array}{l}\mathrm{C} 2 \mathrm{a} \\
\mathrm{C} 2 \mathrm{a} \\
\mathrm{C} 2 \mathrm{~b} \\
\mathrm{C} 2 \mathrm{~b} \\
\mathrm{C} 2 \mathrm{~b} \\
\mathrm{C} 2 \mathrm{~b} \\
\mathrm{C} 2 \mathrm{~b} \\
\mathrm{C} 2 \mathrm{c} \\
\mathrm{C} 2 \mathrm{c} \\
\mathrm{C} 2 \mathrm{c} \\
\mathrm{C} 2 \mathrm{c} \\
\mathrm{C} 2 \mathrm{c} \\
\mathrm{C} 2 \mathrm{a} \\
\mathrm{C} 2 \mathrm{~b} \\
\mathrm{C} 2 \mathrm{~b}\end{array}$ & $\begin{array}{l}\text { Brisou 3617, sea water, Oléron } \\
\text { Brisou 3736, sea water, Oléron } \\
\text { NCTC } 9493 \\
\text { Brisou } 6912 \text {, sea water, Oléron } \\
\text { Lab. Municipal, spring water, Creysse, } 1971 \\
\text { Lab. Municipal, well water, Izon, 1971 } \\
\text { Lab. Municipal, spring water, Bergerac, } 1971 \\
\text { ATCC } 992 \\
\text { ATCC } 4261 \\
\text { ATCC } 7462 \\
\text { ATCC } 640 \\
\text { NCIB } 8616 \\
\text { NCIB } 4612 \\
\text { NCIB } 8266 \\
\text { NCIB } 8285\end{array}$ & $\begin{array}{l}\text { E } \\
\text { E, S } \\
\text { E, S } \\
\text { E } \\
\text { E } \\
\text { E, S } \\
\text { E, S } \\
\text { E } \\
\text { E, S } \\
\text { E } \\
\text { E } \\
\text { E, S } \\
\text { E } \\
\text { E } \\
\text { E }\end{array}$ & \\
\hline $\begin{array}{l}48 \\
49 \\
50 \\
51 \\
52 \\
53 \\
54 \\
55\end{array}$ & $\begin{array}{l}\text { S. marinorubra } \\
\text { S. marinorubra } \\
\text { S. marinorubra } \\
\text { S. marinorubra } \\
\text { S. marinorubra } \\
\text { S. marinorubra } \\
\text { S. marinorubra } \\
\text { S. marinorubra }\end{array}$ & $\begin{array}{l}\text { LM } 9.60 \\
\text { LM } 36.68 \\
\text { LM } 34.70 \\
\text { LM } 1.74 \\
\text { G } 20 \\
\text { G } 22 \\
\text { G } 36 \\
\text { G } 37\end{array}$ & $\begin{array}{l}\text { B1 } \\
\text { B2 } \\
\text { B1 } \\
\text { B1 } \\
\text { B1 } \\
\text { B1 }\end{array}$ & $\begin{array}{l}\text { ATCC } 266 \\
\text { Animal faeces, Tangier, } 1968 \\
\text { Throat swab, Créteil, } 1970 \\
\text { Urine, Trujillo } \\
\text { Brisou 90, pig } \\
\text { Brisou 658, sea water, La Rochelle, NCTC } 10847 \\
\text { Santé Navale, cultivated mushroom, 1964 } \\
\text { Santé Navale, cultivated mushroom, 1964, } \\
\text { DSM 30124 }\end{array}$ & $\begin{array}{l}\text { E, S } \\
\text { E,S } \\
\text { E,S } \\
\text { E,S } \\
\text { E, S } \\
\text { E,S } \\
\text { E,S } \\
\text { S }\end{array}$ & \\
\hline $\begin{array}{l}56 \\
57 \\
58 \\
59 \\
60 \\
61 \\
62\end{array}$ & $\begin{array}{l}\text { S. marinorubra } \\
\text { S. marinorubra } \\
\text { S. marinorubra } \\
\text { S. marinorubra } \\
\text { S. marinorubra } \\
\text { S. marinorubra }\end{array}$ & $\begin{array}{l}\text { G } 39 \\
\text { G } 230 \\
\text { G } 291 \\
\text { G } 377 \\
\text { G } 511 \\
\text { G } 513 \\
\text { G } 530\end{array}$ & $\begin{array}{l}\text { B1 } \\
\text { B3 } \\
\text { B1 } \\
\text { B3 } \\
\text { B2 } \\
\text { B1 } \\
\text { B2 }\end{array}$ & $\begin{array}{l}\text { Santé Navale, cultivated mushroom, } 1966 \text {, } \\
\text { NCTC } 10848 \\
\text { IP Tunis } 8376,1971 \\
\text { Brisou } 641 \text {, water, La Rochelle } \\
\text { Lapage T37/66, pig faeces } \\
\text { CCM } 788 \\
\text { NCPPB } 1126 \\
\text { Matsumoto, sewage }\end{array}$ & $\begin{array}{l}\text { E, S } \\
\text { S } \\
\text { E, S } \\
\text { E, S } \\
\text { E,S } \\
\text { S } \\
\text { E, S }\end{array}$ & \\
\hline
\end{tabular}

* LM, Strain provided by Dr C. Richard from Collection du Service des Entérobactéries de l'Institut Pasteur de Paris (Professeur L. Le Minor); G, strain from Collection du Dr P. A. D. Grimont (Laboratoire de Bactériologie, Université de Bordeaux II, France) studied by Grimont et al. $(1977 \mathrm{~b})$.

$\dagger$ According to Grimont et al. $(1977 \mathrm{~b})$.

$\ddagger$ ATCC, American Type Culture Collection; CCM, Czechoslovak Collection of Microorganisms; CDC, Center for Disease Control; NCIB, National Collection of Industrial Bacteria; NCPPB, National Collection of Plant Pathogenic Bacteria; NCTC, National Collection of Type Cultures. Brisou, Prof. J. Brisou, Poitiers University, France; I. P. Tunis, Institut Pasteur de Tunis, Tunisia (R. Houissa); Lab. Municipal, Laboratoire Municipal, Bordeaux, France (R. Serceau); Lapage, Dr S. Lapage, Central Public Health Laboratory, London; Matsumoto, Dr H. Matsumoto, Shinshu University, Matsumoto, Japan; Santé Navale, Ecole du Service de Santé des Armées, Bordeaux, France.

$\S \mathrm{E}$, Bacteria harvested during the exponential phase; S, bacteria harvested during the stationary phase. 


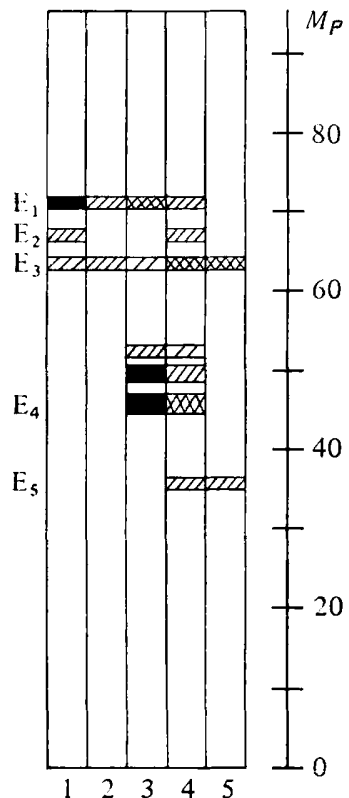

(a)

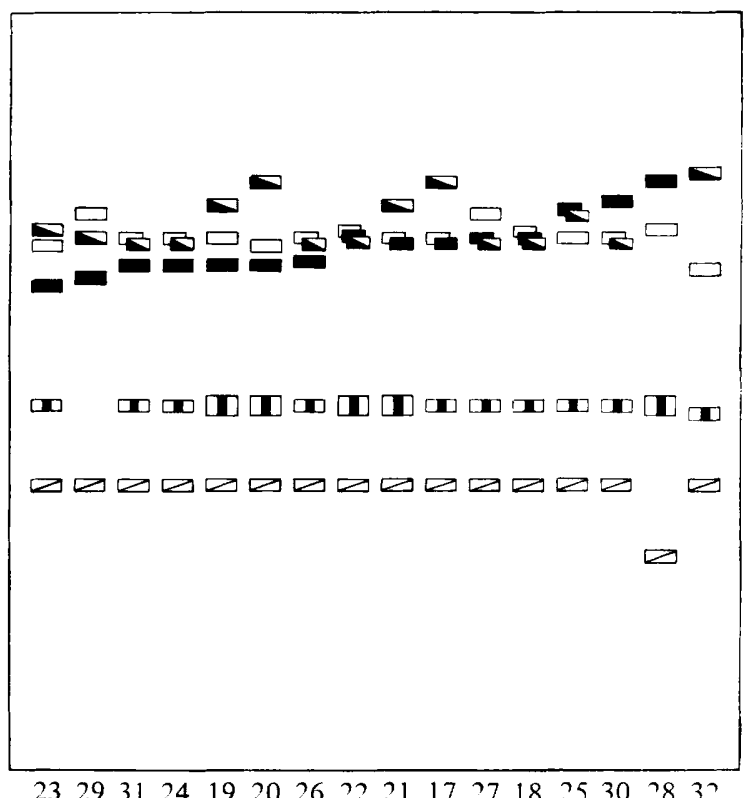

(b)

Fig. 1. Serratia liquefaciens. (a) Schematic representation of mobility and activity of esterase bands (strain 19). Horizontal slab acrylamide-agarose gel electrophoresis was performed using $7 \%(w / v)$ acrylamide and discontinuous Tris/glycine buffer, $\mathrm{pH} 8.7$ (Uriel, 1966). Esterase activity was revealed by the method of Uriel (1961). Substrates used were: $1, \alpha$-naphthyl acetate; $2, \alpha$-naphthyl butyrate; 3 , indoxyl acetate; $4, \beta$-naphthyl acetate; $5, \beta$-naphthyl butyrate. Relative intensity of staining: $>>\square D>\square \triangle>\square D$. (b) Esterase patterns of the 16 strains (numbered as in Table 1) arranged in order of increasing mobility of $E_{3}$ esterase bands. $\square, E_{1}$ band; $\square, E_{2}$ band; $\square, \mathrm{E}_{3}$ band; $\square, \mathrm{E}_{4}$ band (only the slowest moving band is represented); $\square, \mathrm{E}_{5}$ band. The $M_{F}$ values were used only comparatively.

the $\mathrm{E}_{3}$ band hydrolysed $\beta$-naphthyl esters and to a lesser degree the other substrates. The $\mathrm{E}_{4}$ band, which reacted strongly with indoxyl acetate and weakly with $\beta$-naphthyl acetate, was broad and consisted of three sub-bands; the $\mathrm{E}_{5}$ band was active towards $\beta$-naphthyl esters.

Band $E_{1}$ was inhibited by $10^{-4} \mathrm{M}-\mathrm{DFP}$ and bands $\mathrm{E}_{3}$ and $\mathrm{E}_{5}$ were inhibited by $10^{-3} \mathrm{M}$, whereas bands $E_{2}$ and $E_{4}$ remained active under these conditions.

\section{Serratia liquefaciens}

The five principal bands were found in $13 \mathrm{~S}$. liquefaciens strains (Fig. $1 \mathrm{~b}$ ). Differences in mobility between bands $E_{1}, E_{2}$ and $E_{3}$ were generally small and two or three of these bands were superimposed in some strains: $E_{1}$ and $E_{2}$ for strains $24,26,30$ and $31 ; E_{1}$ and $E_{3}$ for strains 25 and $27 ; E_{2}$ and $E_{3}$ for strains 17 and 21 ; and all three bands for strains 18 and 22 . Separation and characterization of bands was then achieved by varying the concentration of acrylamide and by differential DFP inhibition. In each strain, bands $E_{4}$ and $E_{5}$ showed electrophoretic uniformity with the exceptions of strain $29\left(\mathrm{E}_{4}\right.$ band) and strain $28\left(\mathrm{E}_{5}\right.$ band). Variations in esterase mobility between the strains distinguished at least 13 electrophoretypes. For strains 21 and 23, similar esterase patterns were obtained after growth at $30{ }^{\circ} \mathrm{C}$ and $37^{\circ} \mathrm{C}$. 


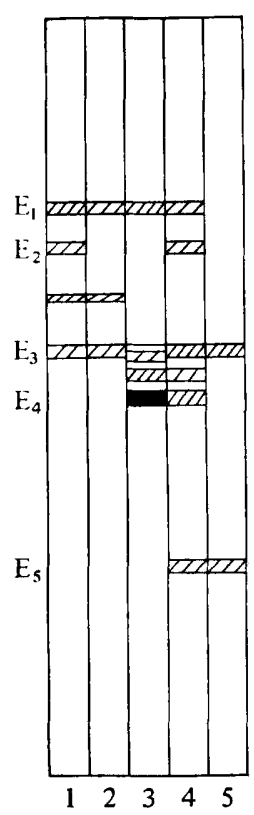

(a)

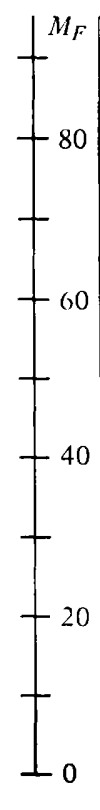

9

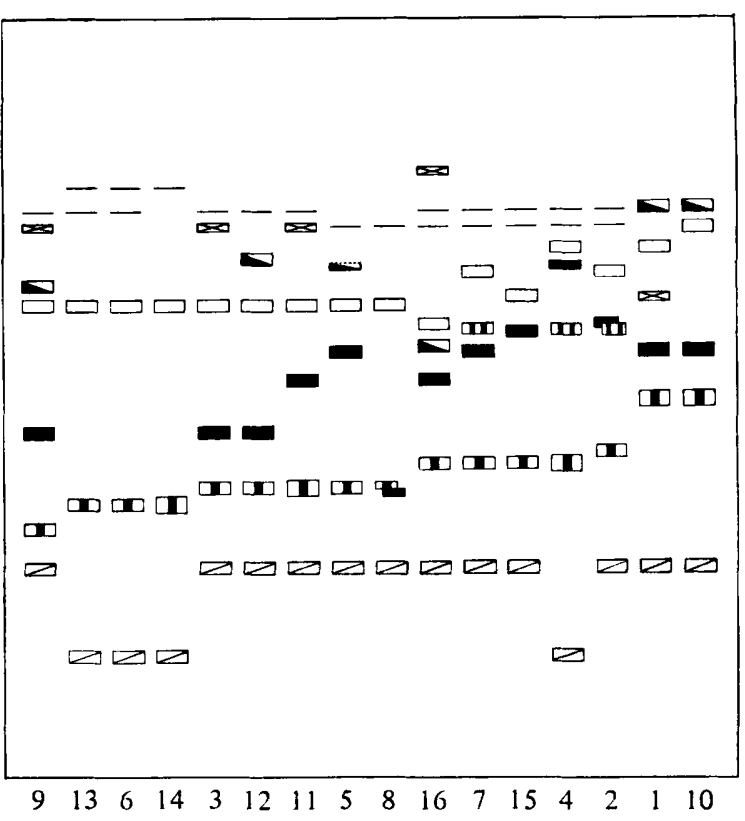

(b)

Fig. 2. Serratia marcescens. (a) Schematic representation of mobility and activity of esterase bands (strain 1). (b) Esterase patterns of the 16 strains arranged in order of increasing mobility of $E_{4}$ bands. Experimental conditions, relative intensity of staining and key as in legend to Fig. 1. W, Esterase band hydrolysing $\alpha$-naphthyl acetate and indoxyl acetate; $\varangle$, esterase band hydrolysing $\alpha$-naphthyl acetate and $\alpha$-naphthyl butyrate.

\section{Serratia marcescens}

The esterase bands of $S$. marcescens strains were more widely spaced and their activity was generally less marked than in $S$. liquefaciens (Fig. $2 a$ ). Bands $\mathrm{E}_{2}, \mathrm{E}_{4}$ and $\mathrm{E}_{5}$ were resolved in all strains but band $\mathrm{E}_{1}$ was defined in only six of the organisms (Fig. 2b). Bands from bacteria harvested during stationary phase were more pronounced. Bands $E_{1}, E_{2}$ and $E_{3}$ were distinctly separated from each other. Band $\mathrm{E}_{4}$ showed electrophoretic heterogeneity, while band $\mathrm{E}_{\overline{5}}$ exhibited two different mobilities: $M_{F} \approx 15$ and $M_{F} \approx 26$ (like strain 28 of $S$. liquefaciens). In some strains two additional moderately coloured bands were detected: one hydrolysing $\alpha$-naphthyl acetate and $\alpha$-naphthyl butyrate and inhibited by $10^{-4} \mathrm{M}$-DFP (strains 1, 3, 9, 11 and 16); another hydrolysing $\alpha$-naphthyl acetate and indoxyl acetate and remaining active at $10^{-3} \mathrm{M}$-DFP (strains 2, 4 and 7). Some minor bands were active towards acetate esters and resistant to DFP. Fourteen electrophoretypes were distinguished, and for strains 1 and 12 similar patterns were obtained after growth at $30^{\circ} \mathrm{C}$ and $37^{\circ} \mathrm{C}$.

\section{Serratia plymuthica}

Bands $E_{1}, E_{4}$ and $E_{5}$ were resolved in all strains (with the exception of strain 39 for band $E_{4}$ ), whereas band $E_{3}$ was defined within biovar $C 2 b$ only (Fig. 3). The latter was more prominent and migrated faster than the corresponding band of $S$. marcescens and $S$. liquefaciens, and was inhibited by $10^{-3} \mathrm{M}$-DFP. In biovars $\mathrm{C} 2 \mathrm{a}$ and $\mathrm{C} 2 \mathrm{~b}$, the $\mathrm{E}_{1}$ band exhibited electrophoretic heterogeneity but bands $\mathrm{E}_{4}$ and $\mathrm{E}_{5}$ were electrophoretically homogeneous, with the single exception of strain 39 for band $\mathrm{E}_{5}$. In biovar $\mathrm{C} 2 \mathrm{c}$, band $\mathrm{E}_{4}$ migrated slower than band $E_{5}$ and all three bands exhibited electrophoretic homogeneity. Nine electrophoretypes were found in biovar $\mathrm{C} 2 \mathrm{a}$ and $\mathrm{C} 2 \mathrm{~b}$, but only one was found in biovar $\mathrm{C} 2 \mathrm{c}$. Congruence was found between the biovars and esterase patterns. 


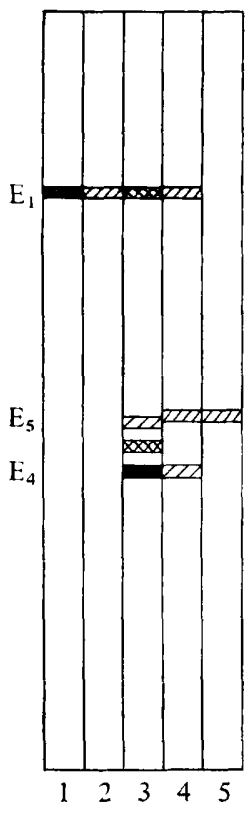

(a)

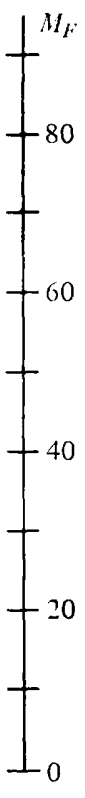

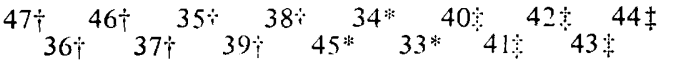

(b)

Fig. 3. Serratia plymuthica. (a) Schematic representation of mobility and activity of esterase bands (strain 41). (b) Esterase patterns of the 15 strains arranged according to biovar, in order of increasing mobility of $\mathrm{E}_{3}$ esterase bands (*, biovar $\mathrm{C} 2 \mathrm{a}$; $\dagger$, biovar $\mathrm{C} 2 \mathrm{~b}$; $\ddagger$, biovar $\mathrm{C} 2 \mathrm{c}$ ). Experimental conditions, relative intensity of staining and key as in legend to Fig. 1.

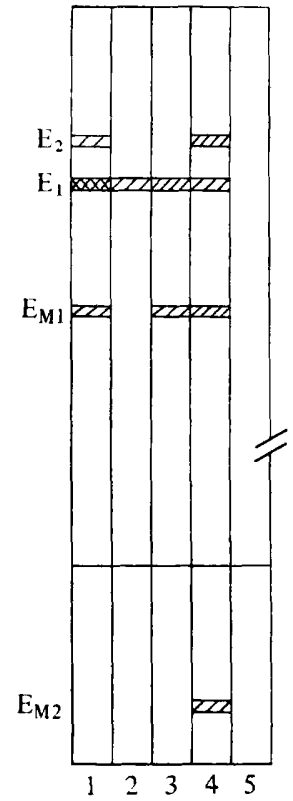

(a)

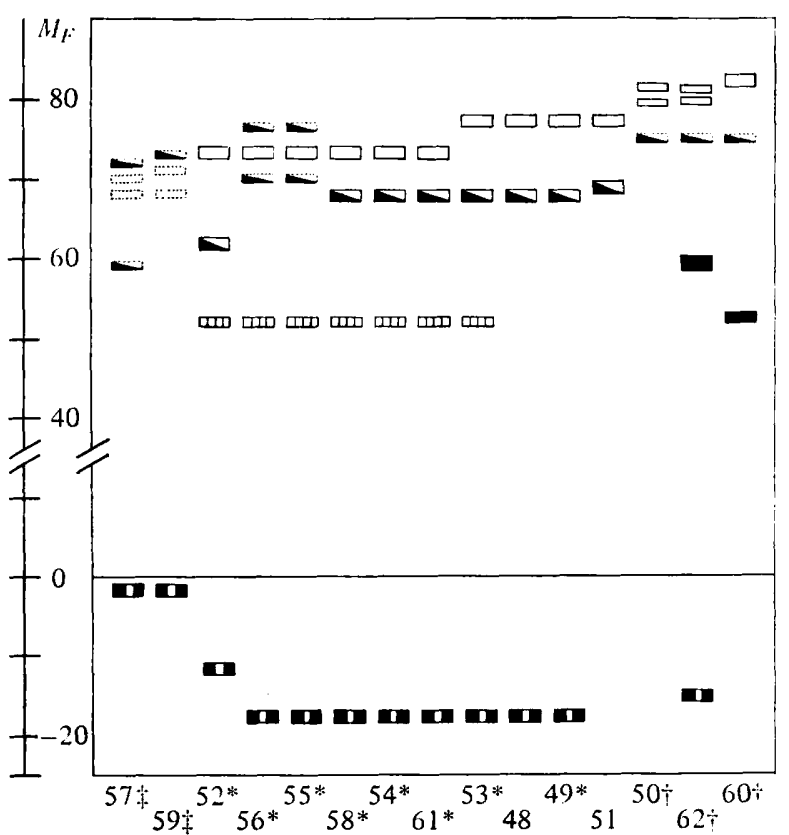

(b)

Fig. 4. Serratia marinorubra. (a) Schematic representation of mobility and activity of esterase bands (strain 58). (b) Esterase patterns of the 15 strains arranged in order of increasing mobility of $E_{2}$ esterase bands (*, biovar B1; $\dagger$, biovar B2; $\$$, biovar B3). Experimental conditions, relative intensity of staining and key as in legend to Fig. 1. 띠, Esterase band hydrolysing acetate esters; II, cathodic band. 
Table 2. $M_{F}$ values of esterase bands in the four species of Serratia

Mean $M_{F}$ values are given together with the standard deviation. Sample sizes are given in parentheses.

$\begin{array}{lcccc}\text { Band } & \text { S. marcescens } & \text { S. liquefaciens } & \text { S. plymuthica } & \text { S. marinorubra } \\ \mathrm{E}_{1} & 64 \cdot 50 \pm 6 \cdot 35(6) & 68 \cdot 27 \pm 3 \cdot 01(15) & 68 \cdot 27 \pm 4 \cdot 98(15) & 67 \cdot 38 \pm 2 \cdot 20(8) \\ \mathrm{E}_{2} & 60 \cdot 88 \pm 3 \cdot 50(16) & 66 \cdot 06 \pm 1 \cdot 57(16) & & 76 \cdot 00 \pm 3 \cdot 24(13) \\ \mathrm{E}_{3} & 50 \cdot 23 \pm 7 \cdot 34(13) & 65 \cdot 00 \pm 3 \cdot 80(15) & 80 \cdot 83 \pm 2 \cdot 86(6) & 55 \cdot 50 \pm 4 \cdot 95(2) \\ \mathrm{E}_{4} & 37 \cdot 75 \pm 4 \cdot 40(16) & 44 \cdot 93 \pm 0 \cdot 26(15) & 40 \cdot 86 \pm 2 \cdot 98(14) & \\ \mathrm{E}_{5} & 23 \cdot 25 \pm 4 \cdot 92(16) & 34 \cdot 44 \pm 2 \cdot 25(16) & 37 \cdot 40 \pm 5 \cdot 58(15) & \\ \mathrm{E}_{\mathrm{Mx}} & & & & -14 \cdot 58 \pm 6 \cdot 16(12) \\ \mathrm{E}_{\mathrm{M2} 2} & & & & \end{array}$

\section{Serratia marinorubra}

Only faint esterase bands were observed with bacteria harvested in exponential phase but in those from stationary phase the bands were defined more clearly (Fig. 4). Band $E_{1}$ migrated more slowly than $\mathrm{E}_{2}$ and was inhibited by $5 \times 10^{-5} \mathrm{M}$-DFP. In some strains, especially in biovar B3, these bands were very faint. Band $E_{3}$ was present in two strains only and bands $E_{4}$ and $E_{5}$ were not detected. Two additional bands, both sensitive to DFP, were visualized: the one in biovar $\mathrm{B} 1$, designated $\mathrm{E}_{\mathrm{M} 1}$, hydrolysed acetate esters and was inhibited by $10^{-5} \mathrm{M}$-DFP; the other, which was present in all three biovars and designated $\mathrm{E}_{\mathrm{M} 2}$, migrated cathodically, hydrolysed $\beta$-naphthyl acetate and was inhibited by $10^{-4} \mathrm{M}-$ DFP. Eleven electrophoretypes were distinguished, and for the 13 strains of known biovar, good correlation was obtained between the biovars and esterase patterns.

\section{DISCUSSION}

Nine types of esterase bands differing in their hydrolysing activity towards carboxylic esters, sensitivity to DFP and electrophoretic mobility were found in extracts of Serratia strains. The distribution of the esterases varied among species (Figs 1 to 4; Table 2). Band $\mathrm{E}_{1}$ was observed in all four Serratia species but was absent in numerous strains. The mobility of band $\mathrm{E}_{2}$ increased from $S$. marcescens through to $S$. marinorubra (Table 2) but was not resolved in $S$. plymuthica strains. The mobility of band $\mathrm{E}_{3}$ increased from $S$. marcescens through to $S$. plymuthica, its electrophoretic distribution ranging from $M_{F} \approx 36$ (Fig. 2) to $M_{F} \approx 83$ (Fig. 3). Bands $\mathrm{E}_{4}$ and $\mathrm{E}_{5}$ were present in all strains of $S$. liquefaciens, $S$. marcescens and $S$. plymuthica, with two exceptions for band $\mathrm{E}_{4}$ in strains 29 and 39 , but were not detected in $S$. marinorubra. The distance between bands $\mathrm{E}_{4}$ and $\mathrm{E}_{5}$ decreased from $S$. marcescens through to $S$. plymuthica. For each of the principal bands $S$. marcescens exhibited the slowest mobility. Additional bands were observed in some $S$. marcescens and $S$. marinorubra strains.

The finding that Serratia species may be characterized by the distinct electrophoretic patterns of their esterases agrees with earlier reports for Proteus and Providencia (Goullet, 1975), Salmonella (Goullet, 1977), Levinea malonatica, Levinea amalonatica and Citrobacter (Goullet \& Richard, 1977). The differentiation of Serratia by esterase profiles is consistent with the results obtained by numerical taxonomy (Bascomb et al., 1971; Grimont et al., 1977b), DNA hybridization (Steigerwalt et al., 1976) and electrophoresis of proteases (Grimont et al., 1977a). On the basis of the esterase profiles in the present study, S. marcescens, $S$. liquefaciens and $S$. plymuthica appear to be more closely related to one another than to $S$. marinorubra. Differentiation of a biovar within $S$. plymuthica and $S$. marinorubra by esterase bands was possible. The numerous electrophoretypes observed within Serratia species could represent a potential method for epidemiological analyses. 
The author thanks Drs C. Richard and P. A. D. Grimont for Serratia strains, and Madame Colette Gaillard and Mademoiselle Catherine Lamesch for technical assistance. This work was supported by grants from the Université de Paris VII and from the Institut National de la Santé et de la Recherche Médicale (no. 75.1.114.1 and no. 78.1.136.1).

\section{REFERENCES}

Bascomb, S., LAPage, S. P., Wilcox, W. R. \& Curtis, M. A. (1971). Numerical classification of the tribe Klebsielleae. Journal of General Microbiology 66, 279-295.

Goullet, PH. (1973). An esterase zymogram of Escherichia coli. Journal of General Microbiology 77, 27-35.

Goullet, РH. (1975). Esterase zymograms of Proteus and Providencia. Journal of General Microbiology 87, 97-106.

Goullet, PH. (1977). Relationships between electrophoretic patterns of esterases from Salmonella. Journal of General Microbiology 98, 535-542.

Goullet, Ph. \& Richard, C. (1977). Distinctive electrophoretic patterns of esterases from Levinea malonatica, Levinea amalonatica and Citrobacter. Journal of General Microbiology 98, 543-549.

Grimont, P. A. D., Grimont, F. \& Dulong DE Rosnay, H. L. C. (1977a). Characterization of Serratia marcescens, $S$. liquefaciens, $S$. plymuthica and $S$. marinorubra by electrophoresis of their proteinases. Journal of General Microbiology 99, 301-310.

Grimont, P. A. D., Grimont, F., Dulong DE Rosnay, H. L. C. \& SNeATH, P. H. A. (1977b). Taxonomy of the genus Serratia. Journal of General Microbiology 98, 39-66.

Steigerwalt, A. G., Fanning Richard, G., FifeASBURY, M. A. \& BRENNER, D. F. (1976). DNA relatedness among species of Enterobacter and Serratia. Canadian Journal of Microbiology 22, 121-137.

URIEL, J. (1961). Caractérisation des cholinestérases et d'autres estérases carboxyliques après électrophorèse et immunoélectrophorèse en gélose (application à l'étude des estérases du sérum humain normal). Annales de l'Institut Pasteur 101, 104-119.

URIEL, J. (1966). Méthode d'électrophorèse dans des gels d'acrylamide-agarose. Bulletin de la Société de chimie biologique 48, 969-982. 